\title{
Innovative Approach to the Formation of a System of Strategic Marketing Management of Tourism Enterprises in Conditions of Market Uncertainty
}

\author{
Elena Voskresenskaya, Nataliya Shandova, Alyona Sofiienko \\ Kherson National Technical University, Kherson, Ukraine
}

\begin{abstract}
The main purpose of the study is to develop methodological basis and practical recommendations in respect of the formation of a system of strategic marketing management of enterprises in conditions of market uncertainty. The urgency of solving this scientific problem consists in the fact that the construction of the market structure of the modern economy requires to solve many strategic managerial tasks on different levels. Within this context, one of the important tasks is to elaborate strategic approaches to advance enterprises in the tourism industry, which allow to use the opportunities of the external and internal environment effectively, to minimize the negative impact of environmental factors, to sustain and to develop competitive advantages in the long run.
\end{abstract}

Keywords - marketing, market strategy, strategic system of management, strategic management

\section{Introduction}

Construction of the market structure of the modern economy requires many strategic tasks solution on different levels of management.

Tourism in Ukraine is an industry that is dynamically developing and has a direct and indirect

DOI: 10.18421/TEM93-32

https://doi.org/10.18421/TEM93-32

Corresponding author: Elena Voskresenskaya, Kherson National Technical University, Kherson, Ukraine Email: e.e.voskresenskaya@gmail.com

Received: 25 February 2020.

Revised: 18 May 2020.

Accepted: 26 May 2020.

Published: 28 August 2020.

(c) BY-NC-ND (C) 2020 Elena Voskresenskaya, Nataliya Shandova \& Alyona Sofiienko; published by UIKTEN. This work is licensed under the Creative Commons AttributionNonCommercial-NoDerivs 4.0 License.

The article is published with Open Access at www.temjournal.com influence on the development of the entire infrastructure of the country's regions. In the future, its importance as a kind of economic activity will undoubtedly be growing.

In Ukraine, tourism is recognized as one of the sectors that needs priority development. In recent years, there has considerably been risen an interest in the development of tourist services by public authorities as an industry that is enabled to make an essential contribution into the revenue of the country's budget.

Within this context, one of the important tasks is to elaborate strategic approaches to advance enterprises in the tourism industry, which allow to use the opportunities of the external and internal environment effectively, to minimize the negative impact of environmental factors, to sustain and to develop competitive advantages in the long run.

\section{Analysis of Recent Research and Publications on the Problem}

A significant scientific contribution into the study of the problems of the formation of marketing strategies was made by the following domestic and foreign scientists: Burdenyuk T.G. [1], Shershniova Z.E. [7], Wagner I. [11] and others. The scientific works by the mentioned authors highlight the issues of forming the principles of strategic marketing, classifying the types of marketing strategies, methodological approaches concerning marketing planning and marketing strategies using.

\section{Research Results}

Problems associated with the strategic marketing management of tourism enterprises in the conditions of uncertainty in the market environment are aimed at implementing the system approach to achieve the interrelated goals of the enterprise. At the same time, one of the biggest problems of implementing the system approach in the tourist enterprises is the lack of clear recommendations for transforming of 
marketing research into strategic management decisions, which are mainly grounded by the availability of certain factors of macro- and microeconomic impact. The analysis of the possible transformation of marketing research into strategic management decisions can be done by means of applying the appropriate methodological tools.

Most of the decisions that the management has to make are based on the data of the subsystems, elements, and their behaviour in time under the influence of changes in market conditions. Frequent changes in the elements of macro- and microeconomic influences result in to a change in the relationships between the elements of the system. Therefore, the following problem emerges before such a system - the dynamic management of the totality of the system elements in conditions of market uncertainty [3].

The system of management of strategic marketing activities in the tourist enterprises (Figure 1) must have two levels. The first level (contour I) is an information system of strategic marketing management; the second level (contour II) is a management system of strategic marketing management.

The marketing information system of the tourist enterprise includes specialists, equipment and methods for collecting, sorting, analyzing, evaluating and distributing timely and reliable information that is used in making marketing decisions.

The role of the marketing information system lies in defining the information needs for marketing management, its receiving and providing the relevant specialists timely.

For the effective functioning of a tourist enterprise in the context of intense competition, information doesn't become less important resource of an enterprise - than finances and personnel. The marketing information system helps the travel company to significantly reduce the risk, to identify difficulties and problems timely, to coordinate the implementation of marketing plans and strategies, to evaluate market activity, to analyze the state of the macro environment, the micro environment and the internal environment of the enterprise [7].
Contour I - the marketing information system is a systematic collection, processing and analysis of data and allows to reduce uncertainty and to minimize the risk in the process of making marketing decisions.

The information, by the way of receiving it, is divided into primary and secondary.

Primary information is aimed at solving a specific problem and is formed in the course of conducting special studies (surveys, observations, etc.).

Secondary information is a data on the macro- and microenterprise of a tourist enterprise, derived from accounting, statistics, special publications, and reference books. All information gathered in the course of marketing research and being necessary to carry out marketing activities, is called the information marketing system.

Sources of internal information can be: reviews of tourist markets; national statistics; statistics of the socio-demographic status of the population.

Internal information helps managers and professionals in designing and adopting marketing decisions, but is usually not used apart from other sources and types of information, since it does not contain many necessary information. The main objects of collecting the information of possible components of the macroeconomic influence are: political and legal; economic; social and demographic [1].

The information system of possible components of microeconomic impact is directed at sources and methods by which it is possible to obtain information of events and situations that are formed in the microeconomic marketing environment. As for the system of information of possible components of microeconomic impact, then it is necessary to mention such important research objects as: the situation on the market; existing and potential competitors; consumers; contact audiences.

One of the most common methods for collecting data in marketing is a survey that is used in about $90 \%$ of researches.

Surveys have virtually no alternative in cases where an enterprise needs information about knowledge, beliefs and preferences of consumers when choosing certain tourist products, the degree of their satisfaction, the image of the enterprise, etc. [2]. 


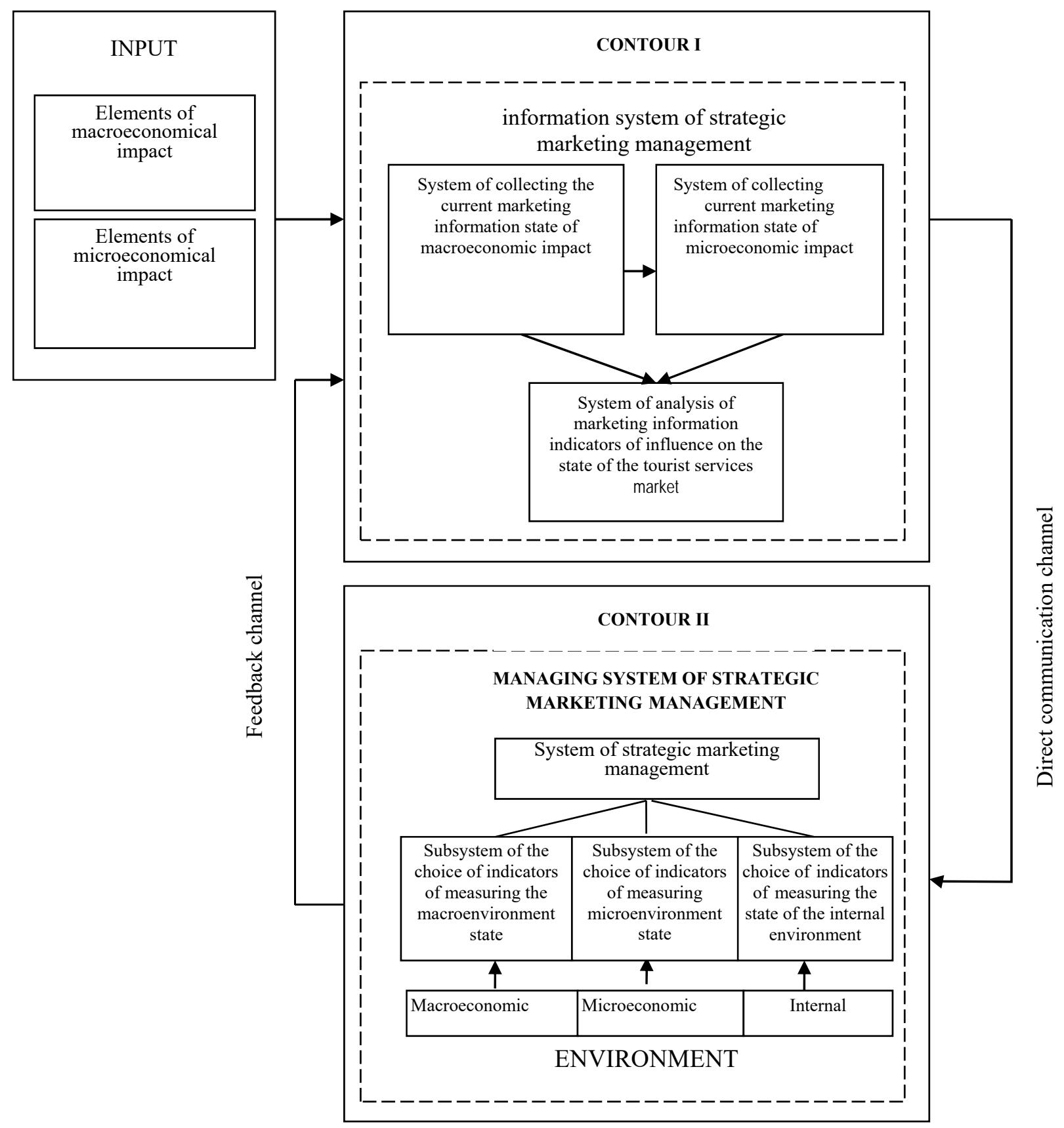

Figure 1. Strategic marketing activity management system for tourist enterprises Source: own development of the authors.

Contour II is a strategic marketing management system that includes the selection of marketing tools, the use of which will allow to make such alternative decisions for the purpose of minimizing the negative impact of changes in the enterprise environment and making the internal environment of the enterprise more favourable to new consumers' preferences, orienting the customer service system on new tastes and preferences. The behaviour and actions of the management system of strategic marketing management fully corresponds to the concept of marketing the relationship between the enterprise and the consumer.

The input of the system implies the relationship of the system with the environment that affects it. And the output out of the system is called the system relationship with the environment that is directed from the system into the environment.

It is assumed that such a system of strategic marketing activities is fully consistent with entrepreneurial behaviour, that is, the relation to predictable and unpredictable changes in the environment retained by the information system, and the problems that are created in this way, the ongoing search for effective alternative solutions that constantly change the state of the company in the direction of positive changes in its financial position. The quality of strategic marketing management changes under the influence of the search for getting profit, the counteraction to the anticipated negative 
impact of changes in the macroenvironment due to changes in operational behaviour of the enterprise with competitors, suppliers, consumers [6].

The system approach flexibly and timely allows to response to changes in all structural elements of the system and environment.

The research of the system allows to determine that integrity and separation are its external properties. While the internal part of the system is not homogeneous, it allows you to divide it into components of the system. The components of the system that are indivisible and the smallest ones are elements of the system. Elements of the system are selected depending on the purpose that is put into its simulation.

The system of strategic marketing management is aimed at achieving the strategic objectives of the enterprise, namely: improving the system of strategic enterprise management through identifying and minimizing the impact, analysis, control, information provision of the strategic marketing management process of the enterprise in order to increase the efficiency of their use and improvement; foreseeing the further development of the situation of uncertainty in the market environment; improvement of planning techniques.

The process of formation of the system of strategic marketing management of tourist enterprises should be carried out step by step: phase I - the establishment of interrelated goals of the enterprise; phase II - the selection of criteria for the analysis of the most successful measuring indicators of the state of the macroeconomic, microeconomic and internal enterprise environment; phase III - the identification of methods for achieving the objectives of the enterprise; phase IV - the selection of strategic marketing management tools; phase $\mathrm{V}$ - making the optimal decision regarding the choice of marketing strategy for the tourist enterprises development.

Adapted to the specificity of functioning of the tourist services market model of the system of management of strategic marketing activities in the tourist enterprises includes: classification of the specified goals; criteria for choosing the most successful measuring indexes and taking into account the influence of the macro- and microenvironment; tools to achieve the goals that have been set up for making the optimal decision.

It is proposed to conduct the further study of the peculiarities of the tourist enterprises operation and to consider the key problems of the tourist services market development; to evaluate the state and prospects of the tourist enterprises development in Kherson region; to investigate the factors of macroand microeconomic influence on the purchasing power of tourists; to carry out a comprehensive analysis of enterprises-participants in the tourist market for the further formation of the strategic marketing management system.

Subsequently, the selection of the most influential indicators of the system of macro- and microeconomic impact on purchasing power and the socio-demographic composition of tourist services is done in Figure 2.

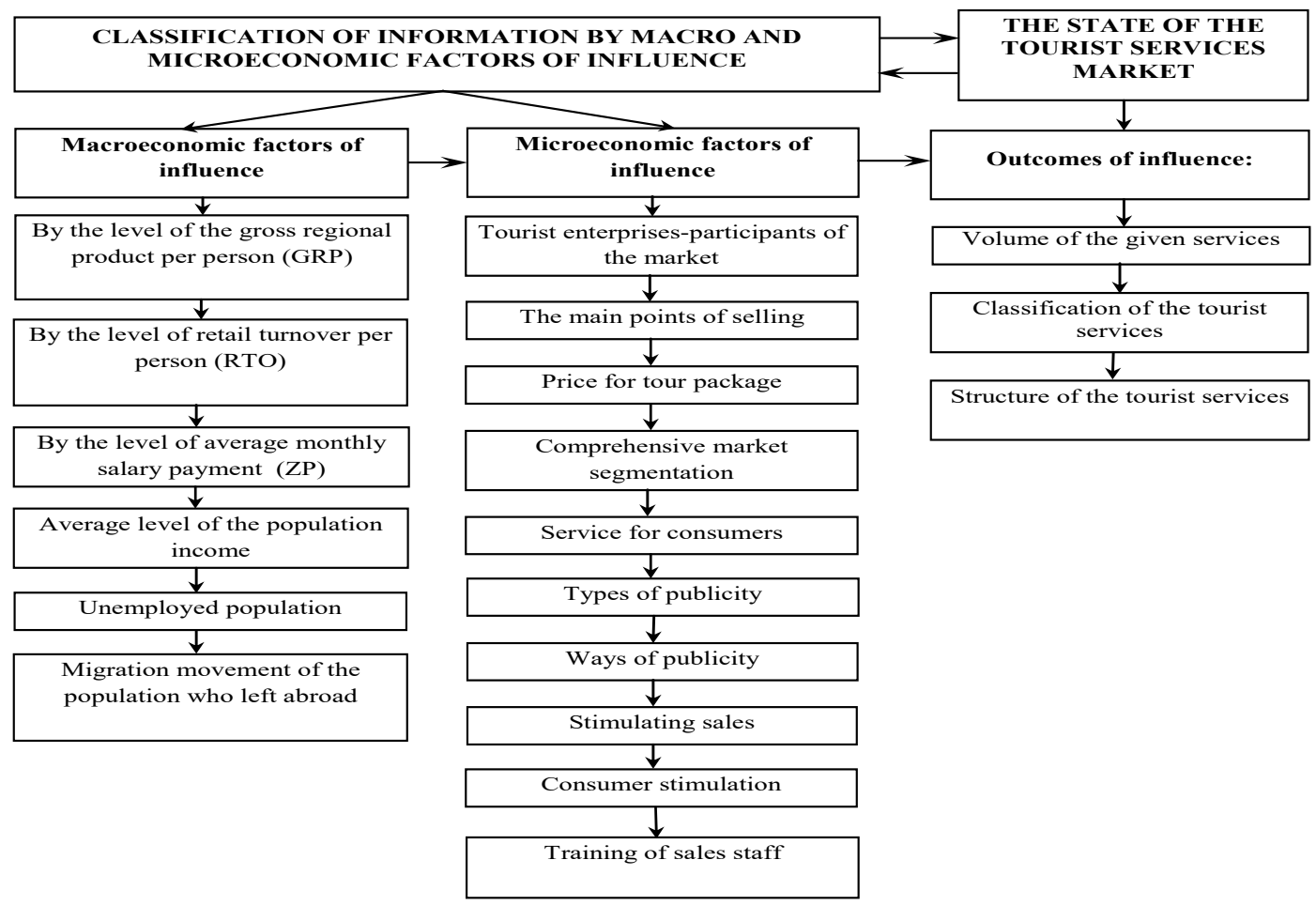

Figure 2. A consolidated information system of indicators of the impact on the state of the tourist services market Source: own development of the authors. 
The formation of a consolidated information system of indicators of the impact on the state of the tourist services market is necessary to determine and predict changes in the market situation for tourism services by means of changing the indicators of macro- and microeconomic impact. The marketing control subsystem will be able to reduce the negative impact level to a minimum in consequence of the selection done in the favour of the most influential indicators.

The analysis of macroeconomic impact factors have been fulfilled is confirmed by the availability of the dependence between the volume of tourist flows of the traveling population abroad and factors such as: the volume of GRP, average income level of the population, the level of social payouts, the level of migration movement [5].
The dependence of tourist flows on the GRP level showed an intimate type of relationship, as indicated by the correlation coefficient (0.7079). The relationship between factors such as: the average income level (correlation coefficient of 0.6522) and social payouts to the population (correlation coefficient 0.66567 ) is average, that is, the higher the population income is, the more opportunity it has to travel abroad. The unemployed factor showed a weak type of relationship, which confirms the correlation coefficient (0.4555). Such a factor as the level of migration of the population, showed the average type of relationship (correlation coefficient 0.6657) (Table 1.).

Table1. Dependence of the demand for tourist services on macroeconomic influential factors

\begin{tabular}{|c|c|c|c|}
\hline Regression equation & $\begin{array}{c}\text { Determination } \\
\text { coefficient }\end{array}$ & $\begin{array}{c}\text { Correlations } \\
\text { coefficient }\end{array}$ & The nature of relationship \\
\hline \multicolumn{4}{|c|}{ Dependence of tourist flows volumes on the volume of GRP } \\
\hline $\mathrm{y}=0,0029 x+14369$ & 0,5011 & 0,7079 & intimate \\
\hline \multicolumn{4}{|c|}{ Dependence of tourist flows volumes on the average level of the population incomes } \\
\hline$y=0,9383 x+14644$ & 0,4254 & 0,6522 & average \\
\hline \multicolumn{4}{|c|}{ Dependence of tourist flows volumes on the level of the unemployed population } \\
\hline$y=-2,7486 x+21154$ & 0,2075 & 0,4555 & weak \\
\hline \multicolumn{4}{|c|}{ Dependence of tourist flows volumes on social payments to the population } \\
\hline$y=0,0069 x+14695$ & 0,4313 & 0,6567 & average \\
\hline \multicolumn{4}{|c|}{ Dependence of tourist flows volumes on the migrated population movement left abroad } \\
\hline$y=-48,524 x+18047$ & 0,4432 & 0,6657 & average \\
\hline
\end{tabular}

Source: author's calculations based on Official site of the State Statistics Service of Ukraine [11].

In order to study the microeconomic influence factors on the choice of marketing strategy, it is proposed to conduct an analysis of the economic activity of enterprises of the tourism industry with the help of such strategic marketing tools as: SWOTanalysis, $\mathrm{ABC}-\mathrm{XYZ}$ analysis and BGM matrix. The use of these tools allows to identify the strengths and weak points of the enterprise, with the goal of further developing opportunities and eliminating threats at the enterprises of the tourist industry in the Kherson region (SWOT-analysis). The grouping of tourism enterprises by the volume of the services provided and the coefficient of variation (ABC and XYZanalysis) is performed to identify the ways of improving the efficiency of enterprises and timely decision-making regarding the behavior of the enterprises in the market. The construction of the BCG matrix allows to set up enterprises on matrices quadrants according to the ratio of the relative market share / growth market rate of the further development of grounded decisions regarding the choice of market strategies of enterprises with the aim of obtaining the maximum possible profits and strengthening competitive positions.
It is proposed to calculate three options for choosing a business strategy for the development of tourism enterprises depending on the probability of taking into account the level of influence of changes in the macro and micro environment. To simplify the forecast estimates, it is recommended to apply the probability indicators with the coefficients:

$$
\alpha=0,7 \text { or } 0,3 ; \beta=0.3 \text { or } 0.7 ; \alpha=0.5 ; \beta=0.5 \text {. }
$$

The use of the methods mentioned above for the enterprises of the tourism industry in the Kherson region permitted us to construct a matrix for choosing the business development strategy of LLC "Tour Plaza" (representative of the most important group of participants in the regional tourism services market), which implies that the strategy of selective development requires the enlargement of the limited investment resources and improvement of the service spectrum quality.

The next step is to establish a relationship between both the organizational management and marketing spheres in the service market.

In order to satisfy maximally the needs of the consumer, it is necessary to study systemically its 
market needs. The task of marketing should consist in the fact that the objective competitive advantages of the company relied on the subjective consumer's perception of the offered services.

By the way of systematic accounting of market needs and market conditions, an enterprise should use its resources and capabilities so that the benefits of the consumer will appear to be optimal. On the other hand, the task of marketing lies in the fact that the company's objective competitive advantages rely on the subjective consumer's perception of the offered services.

The principle of management is defined as the regularities that interact between different structures of the management system and manifest themselves when setting up the practical management tasks.

One of the main and important tendencies of marketing research is the consumers' research to meet best their needs.

When conducting marketing research on consumer behavior in the tourist services market, it is necessary to pay attention first of all to the fact that the consumer's relation to tourist services is mainly based on the quality of service, the conditions of guarantee service of the consumers on the tourist routes.

Determining the quality of non-material services, which is mainly a tourist service, is very difficult and often this concept in the consumer is associated with the notion of the image of the tourist enterprise providing an appropriate service.

Taking into account the concept of "image" of the enterprise existing in management, when investigating the consumer's behavior, management indicators were used to characterize the organizational, industrial and economic potential of the company that is closely related with the impact on the enterprise's image (competence of the personnel's performance, compliance with the term of providing a service, internal atmosphere of the enterprise, working experience in the relevant market of services, high quality services providing, privileges and discounts that the company provides socially unsecured layers of the population).

The indicators mentioned above are related to the management sphere, and it can be argued that there is an intimate relationship between both the management and the marketing fields in the tourist enterprise, if we consider the behavior of the consumer when choosing a tourist service and the influence of the characteristics of the image mentioned above, the perception of a service and the satisfaction received from its use [4].

Consumer's behaviour in terms of marketing in the tourist market can be assessed through researching:
- degree of the consumer's constancy in using the services of the given enterprise and the opportunity to analyze short-term changes in demand for the tourist changes;

- emotional and personal perception of a tourist service that can be characterized by: a) the work of the office staff (friendly attitude towards the client, friendly working atmosphere, attentiveness and courtesy in personal communication with the client, etc.); b) comfortable design of the office space and convenient stay of the client in it; c) the efficiency of providing the source information and the information sources accessibility that will help to offer the client the most prosperous choice among many other alternatives available;

- socio-demographic characteristics of the consumer, which ultimately affect its purchasing power and efficiency of the tourist service using.

The list of all characteristics and their selection is based on the analysis of the indicators of the macroeconomic impact on the state of the tourist services market.

The information about the consumers can be obtained through their being interviewed. At the moment, one of the most widespread ways of obtaining such information is a questionnaire.

In marketing, the questionnaire is presented as one of the research methods. Its essence consists in questioning the target audience on the basis of an interviewer's questionnaire [8].

The questionnaire allows to solve several important tasks immediately, namely: 1) to determine the degree of the marketing and management influence on the tourist enterprise when forming the tourist services; 2) to define the consumer's relation to a tourist service proposed.

Many experts believe that management involves marketing as an approach that appeared in connection with the buyer's market formation. Marketing involves management as an active management component along with the market research. Therefore, establishing the relationship between the organizational management and marketing spheres in the services market allows by means of the researching questionnaire to determine the list of the prevailing socio-demographic characteristics of the target consumers of tourism services, the list of microeconomic and internal factors that affect the image of the tourist enterprise and the tourist service perception of high quality.

Mentioned above makes it possible to construct the convergent matrix of the marketing tools and the strategic management decisions (Fig. 3.). 


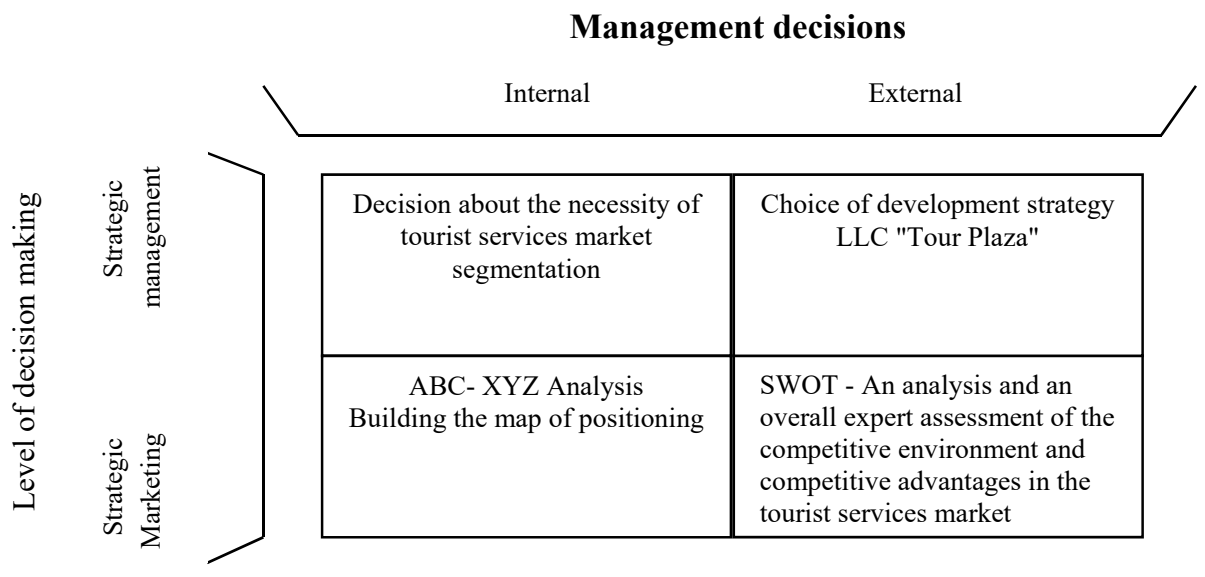

Figure 3. The convergent matrix of the marketing tools and the strategic management decisions Source: own development of the authors.

The proposed matrix helps to strengthen the cooperation of the subjects of management, their consolidation, interaction and interconnections between components of the management system. In this case, the integration between individual subsystems and components of the management system is provided by deepening and specifying the interconnections between them. The very process of marketing integration into management represents the consistency of goals, strategies and tactics between the two spheres of enterprise activity.

Multi-level economic and mathematical processing of the questionnaire research allows to rank and select the most successful indicators for mapping two-level and multi-level segmentation.

The expert assessment of the competitiveness of tourist enterprises of the Kherson region was determined by such factors of competitiveness as: the image of the tourist enterprise, the quality of the tourism product, the number of tours, the range of services, types of tourism provided by individual tourist enterprises.

To determine the location of each of the investigated tourism enterprises in the tourist services market in the regional market, positioning was carried out with the help of such evaluation criteria as: Integral Competitiveness Index and Quality of Travel Services.

The positioning of tourist enterprises in the tourist services market of the Kherson region allows to determine the state of the competitive environment and to choose the most successful competitive strategy [9].

After calculating the integral index of competitiveness it is necessary to construct positioning maps for tourist enterprises of the Kherson region. These cards can perform their functions as operating controls tools if the selected participants in this market segment or the market as a whole have the same organizational and legal characteristics. Therefore, we outline the positioning of tour operators and travel agents in the regional market.

The formation of tourist enterprises types is presented by a set of classification features, which allowed to distinguish five types of enterprises listed in Table 2.

Table 2. Classification of tourist enterprises types of the Kherson market by a set of classification characteristics

\begin{tabular}{|c|c|c|c|}
\hline Type & $\begin{array}{l}\text { List of users of tourist } \\
\text { services of the enterprise }\end{array}$ & $\begin{array}{c}\text { Set of classification } \\
\text { characteristics }\end{array}$ & Tourist enterprises \\
\hline Type A & $\begin{array}{l}\text { 1)Foreign tourists; } \\
\text { 2)Tourists - citizen of } \\
\text { Ukraine leaving abroad; } \\
\text { 3)Domestic tourists. }\end{array}$ & $\begin{array}{c}\text { inbound, } \\
\text { outgoing, domestic }\end{array}$ & $\begin{array}{l}\text { PE Pasichnyk N.O. } \\
\text { PPE Bashmakova O.M } \\
\text { PE Mironova AI. }\end{array}$ \\
\hline Type B & $\begin{array}{l}\text { 1) Foreign tourists; } \\
\text { 2)Domestic tourists. }\end{array}$ & $\begin{array}{l}\text { inbound } \\
\text { domestic }\end{array}$ & $\begin{array}{l}\text { PJSC Tourist Complex "Frigate" } \\
\text { PE "Regatos" }\end{array}$ \\
\hline Type C & $\begin{array}{l}\text { 1)Tourists - citizen of } \\
\text { Ukraine leaving abroad; } \\
\text { 2) Domestic tourists. }\end{array}$ & $\begin{array}{l}\text { outgoing, } \\
\text { domestic }\end{array}$ & $\begin{array}{ll}\text { PAR "Parity" } & \text { PPE Tour agency "Elena } \\
\text { LLC "Tour Plaza" } & \text { Elite Tour" } \\
\text { LLC "Yumis" } & \text { PE Osochenko A.I. } \\
\text { LLC "Air Line Express" } & \text { PE "Regatos-Tour" } \\
\text { PPE Rybak A.L. } & \text { PE Skripka S.V. } \\
\text { PE Polzik U.E } & \text { LLC "Planet" } \\
\text { PE Savchenko M.L. } & \text { PE "Ophir-Tours" }\end{array}$ \\
\hline
\end{tabular}




\begin{tabular}{|l|l|c|ll|}
\hline & & domestic & $\begin{array}{l}\text { PE Novosadova T.L. } \\
\text { PE Serezhnykova T.N. } \\
\text { PE Plyachenko ZK } \\
\text { PE Ohol D.V. }\end{array}$ & $\begin{array}{l}\text { PE Vysoven' G.A. } \\
\text { PE Shelyakin V.V. } \\
\text { PE Grebenyuk V.V. }\end{array}$ \\
\hline Type E & $\begin{array}{l}\text { 1) Domestic tourists. } \\
\text { Ukraine leaving abroad. }\end{array}$ & outgoing & $\begin{array}{l}\text { PE Travel Agency "Veter stranstviy" } \\
\text { PE Trip Bureau "Kvytky po Yevropi" }\end{array}$ \\
\hline
\end{tabular}

Source: own development of the authors.

The formation of detailed characteristics of individual groups of consumers, which, in the case of two-level and multilevel segmentation, are combined into separate segments according to the classification of tourism enterprises improved by the classification in this research. The largest share among these types is occupied by enterprises belonging to type C tourists - Ukrainian citizens traveling abroad + domestic tourists. Multi-level segmentation of tourist services by the representatives of this group - LLC "Tour Plaza" is based on three criteria for consumer assessment, such as: social status, average monthly income and age.

The calculation of the regional market segments allows choosing from them, namely those that will help the "Tour Plaza" Ltd to increase the profitability of its activities and more effectively use limited resources. This approach coincides with the content of the selective development strategy.

According to its economic content, the strategy of selective development of a tourist enterprise is a strategy for establishing and consolidating a longterm competitive position in the selected segments of the tourist services market. Therefore, when forming a system of strategic marketing management, the stages of selection of competitive marketing strategies are necessary. Competition strategies are the basis of competitive behavior of enterprises in the market and describe the scheme of providing advantages over competitors.

Table 3. presents the main advantages and risks associated with the choice of a strategy to achieve competitive advantages that take into account the characteristics of tourism services.

When studying the various factors of the macro environment, it is very important to keep in mind two points. The first is that all factors are in a state of strong interaction. The second is that the degree of influence of individual factors of the macro environment on different types of tourist enterprises manifests itself in different ways [10].

Table 3. Benefits and risks associated with the application of competitive strategies for enterprises in the Kherson tourist services market

\begin{tabular}{|c|c|c|c|}
\hline $\begin{array}{l}\text { Types of competitive } \\
\text { marketing strategies }\end{array}$ & Background & Advantages of the strategy & Risks of strategy \\
\hline $\begin{array}{l}\text { 1. Leadership for account } \\
\text { of expenditures. }\end{array}$ & $\begin{array}{l}\text { A large market share, } \\
\text { strict control of expenses } \\
\text { (PAR "Parity" - } 27,07 \% \text {, } \\
\text { PJSC Tourist complex } \\
\text { "Frigate" - 17,62\%). }\end{array}$ & $\begin{array}{l}\text { Enterprises are profitable even } \\
\text { in conditions of intense } \\
\text { competition } \\
\text { (PAR "Parity" - } 4,09 \%, \\
\text { PJSC Tourist Complex } \\
\text { "Frigate" - } 1.61 \%) \text {. }\end{array}$ & $\begin{array}{l}\text { High degree of uncertainty of } \\
\text { the external environment. }\end{array}$ \\
\hline 2. Differentiation strategy. & $\begin{array}{l}\text { Personal image of the } \\
\text { enterprise. High potential } \\
\text { for improving the quality } \\
\text { of the tourist service by } \\
\text { expanding the service (PE } \\
\text { "Regatos" } \\
\text { PE "Regatos Tour"). }\end{array}$ & $\begin{array}{l}\text { Consumers have personal } \\
\text { preferences for the perception } \\
\text { of individual tourist products } \\
\text { and anticipate its uniqueness, } \\
\text { which creates high entry } \\
\text { barriers for competitors and } \\
\text { allows to increase profits per } \\
\text { customer (PE "Regatos" - } \\
\text { 4,104 thousand UAH, PE } \\
\text { "Regatos Tour" - 0,304 } \\
\text { thousand UAH.). }\end{array}$ & $\begin{array}{l}\text { Possible simulation of tourist } \\
\text { services by competitors, } \\
\text { which will result into } \\
\text { reducing the benefits of } \\
\text { differentiation. Changing the } \\
\text { value system of the } \\
\text { consumer, that can lead to the } \\
\text { loss of a significant number } \\
\text { of target customers. }\end{array}$ \\
\hline $\begin{array}{l}\text { 3. Focusing strategy on the } \\
\text { individual segments. }\end{array}$ & $\begin{array}{l}\text { An enterprise must satisfy } \\
\text { consumers' needs more } \\
\text { effectively than } \\
\text { competitors } \\
\text { (LLC "Tour Plaza", } \\
\text { PE Travel Agency } \\
\text { "Veter Stranstviy). }\end{array}$ & $\begin{array}{l}\text { Possibility of forming a bank } \\
\text { of target consumers and using } \\
\text { a motivational mechanism to } \\
\text { preserve this quantity. }\end{array}$ & $\begin{array}{l}\text { Possible selection of the most } \\
\text { attractive segments of the } \\
\text { market. }\end{array}$ \\
\hline
\end{tabular}

Source: own development of the authors. 
In the conditions of the lack of necessary information, to assess the state of the environment is extremely difficult. The method of expert assessment allows to compensate insufficient amount of information and to take into account experts' opinions regarding the assessment of the environment state. The task of the environment assessment can be solved on the basis of the method of prioritization.
On the basis of expert evaluations of the factors of influence we determine the state of the environment, the assessment of the attractiveness given in Table 4.

To determine the complex impact of the environment on the performance of enterprises, the integral indicator of the state of the environment is calculated. The state of the environment is determined by the regression scale of standards.

Table 4. Assessment of the attractiveness of the macro- and micromarket of the tourist services market

\begin{tabular}{|c|c|c|c|}
\hline Factors of assessment & $\begin{array}{c}\text { Coefficient of } \\
\text { indicators validity }\end{array}$ & Criteria for evaluating factors & $\begin{array}{l}\text { Coefficient of } \\
\text { criteria validity }\end{array}$ \\
\hline \multicolumn{4}{|c|}{ Assessment of the impact on the company of socio-economic trends in the macro environment } \\
\hline $\begin{array}{l}\text { 1. The level of incomes per } \\
\text { household }\end{array}$ & 0,43 & $\begin{array}{l}\text { decrease } \\
\text { stabilization } \\
\text { increase } \\
\end{array}$ & $\begin{array}{l}0,15 \\
0,36 \\
0,49\end{array}$ \\
\hline $\begin{array}{l}\text { 2. Influence level of the unemployed } \\
\text { population }\end{array}$ & 0,17 & $\begin{array}{c}\text { high } \\
\text { average } \\
\text { low }\end{array}$ & $\begin{array}{l}0,15 \\
0,40 \\
0,45\end{array}$ \\
\hline 3. The level of social payouts & 0,12 & $\begin{array}{c}\text { positive } \\
\text { neutral } \\
\text { negative }\end{array}$ & $\begin{array}{l}0,29 \\
0,36 \\
0,35\end{array}$ \\
\hline $\begin{array}{l}\text { 4. Migration movement of the } \\
\text { population }\end{array}$ & 0,11 & $\begin{array}{l}\text { positive } \\
\text { neutral } \\
\text { negative }\end{array}$ & $\begin{array}{l}0,45 \\
0,36 \\
0,19\end{array}$ \\
\hline 5. GRP volume & 0,17 & $\begin{array}{l}\text { decrease } \\
\text { stabilization } \\
\text { increase }\end{array}$ & $\begin{array}{l}0,10 \\
0,52 \\
0,38\end{array}$ \\
\hline \multicolumn{4}{|c|}{ An assessment of the impact of competition within the microenterprise industry } \\
\hline 1. Dynamics of changes in demand & 0,20 & $\begin{array}{c}\text { reduction } \\
\text { stabilization } \\
\text { increase }\end{array}$ & $\begin{array}{l}0,05 \\
0,30 \\
0,65\end{array}$ \\
\hline 2. Number of competitors & 0,08 & $\begin{array}{c}\text { little } \\
\text { big } \\
\text { constantly get increased }\end{array}$ & $\begin{array}{l}0,59 \\
0,15 \\
0,26\end{array}$ \\
\hline 3. Stages of the industry's life cycle & 0,05 & $\begin{array}{l}\text { production } \\
\text { development } \\
\text { saturation } \\
\text { decline }\end{array}$ & $\begin{array}{l}0,30 \\
0,45 \\
0,15 \\
0,10\end{array}$ \\
\hline 4. The size of the input sector barrier & 0,30 & $\begin{array}{l}\text { low } \\
\text { high }\end{array}$ & $\begin{array}{l}0,10 \\
0,90\end{array}$ \\
\hline 5. Aggressiveness of competitors & 0,10 & $\begin{array}{l}\text { low } \\
\text { average } \\
\text { high }\end{array}$ & $\begin{array}{l}0,48 \\
0,38 \\
0,14\end{array}$ \\
\hline $\begin{array}{l}\text { 6. Prospective profitability from the } \\
\text { implementation of a competitive } \\
\text { strategy }\end{array}$ & 0,15 & $\begin{array}{l}\text { above industry average } \\
\text { at averages } \\
\text { below the industry average }\end{array}$ & $\begin{array}{l}0,50 \\
0,32 \\
0,18\end{array}$ \\
\hline $\begin{array}{l}\text { 7. Level of entrepreneurial activity in } \\
\text { the region. }\end{array}$ & 0,12 & $\begin{array}{l}\text { very low } \\
\text { low } \\
\text { rather low } \\
\text { rather high }\end{array}$ & $\begin{array}{l}0,08 \\
0,12 \\
0,22 \\
0,28 \\
0,30 \\
\end{array}$ \\
\hline
\end{tabular}

Source: own development of the authors. 
Determination of the indicator of the complex influence of the macro environment on the effectiveness of the tourist enterprises of the regional tourism services market is carried out according to the following formula:

$$
K=\sum_{i=1}^{n} \Phi_{M a_{i}} \times K_{M a_{j}}
$$

where Fmai - validity coefficient of i-factor of the macroenvironment assessment;

Kmaj - validity coefficient of $j$-criteria by $i-$ factor;

$\mathrm{n}$ - the number of evaluation factors.

It was revealed by expertizing that the minimal complex assessment of the nature of the environment impact on tourist enterprises is 0.11315 , and the maximum - 1.1087 .

The optimal value of the interval is calculated by the formula:

$$
Y=\frac{x_{\max }-x_{\min }}{1+3,2 \lg n}
$$

where $\mathrm{y}$ is an interval length;

Xmax, Xmin - respectively the maximum and minimum levels of evaluation;

$\mathrm{n}$ - number of calculated indicators.

For the given formula the average length for this series is calculated:

$$
Y=\frac{1,1087-0,1315}{2+3,2 \lg n}=0,3019 .
$$

In the same way, the indicator of the complex influence of the microenvironment is determined.

In the course of calculations, four groups of homogeneous assessments of the nature of the external - environment were obtained: critical, unstable, satisfactory, and stable.

The critical state of the environment is characterized by unexpected and completely new developments. Changes in this environment occur much faster than the enterprise reacts to them. The future is unpredictable. The unstable state of the environment has unexpected but similar events in the past. It is possible to predict serious problems in the future. The satisfactory condition of the enterprise indicates that events occur in the usual way. The pace of changes is compared with the reaction of the enterprise. The future is foreseeable. Stable state of the environment has rather familiar events. Changes in this environment occur more slowly than the reaction of the enterprise. The future is predictable.
The development of the marketing strategy of an enterprise should be fulfilled taking into account a systematic approach regarding the strategic marketing management of the enterprise which consists of five stages:

Stage 1 - the impact of each macro-environment on the choice of marketing strategy is determined, the need to determine such an impact is tied with the fact that marketing strategies are largely dependent on the events occurring in the external environment;

Stage 2 - The choice of a marketing strategy depends on the goals of the enterprise. The desire to create a real portfolio of strategies is based on the fact that each strategy is expected to achieve its goals during a long period of time with a certain level of risk for this purpose. This combination gives the opportunity to choose the most realistic strategies;

Stage 3 - Assessment of the impact of the microenvironment on the choice of strategy. Similarly, there is a second-level procedure for choosing strategies that potentially can enter the portfolio;

Stage 4 - Building and analyzing the matrix of strategies case. In this case, it is expedient to use a scenario approach that provides multivariate chosen strategies;

Stage 5 - Identifying the desired enterprise strategies case depending on which of the options can best achieve the goals.

These steps can be considered to be a sequence of the forming process of the strategic marketing management system.

In this study, a scenario of the strategic marketing management system is implemented on the - example of LLC "Tour Plaza". This enterprise is a representative of the most significant group of participants in the regional tourist services market (type C). Taking into account the structural peculiarities of this group, a group of experts has been selected that was able to assess the relevant impact of both macro-environment and microenvironment on domestic and outbound tourism. Having been determined by expert estimations, the matrix of the business and competitive strategy choice for "Tour Plaza" Ltd. has been formed (Table 5). The business strategy chosen for the selective development provides searching for the ways of increasing the competitive advantage by concentrating the investments in the segments where profitability is high and the risk level is low. Among the competitive strategies the following are selected: 1) leadership at the expense of expenditures; 2) differentiation of the service services spectrum; 3 ) focusing on individual segments. 
Table 5. Matrix of Strategy Portfolio Formation of LLC "Tour Plaza"

\begin{tabular}{|c|c|c|c|c|}
\hline \multirow{2}{*}{ Strategies } & \multirow[b]{2}{*}{$\begin{array}{l}\text { Business strategy for } \\
\text { selective development }\end{array}$} & \multicolumn{3}{|c|}{ Competitive strategies } \\
\hline & & $\begin{array}{l}\text { Leadership for } \\
\text { account of } \\
\text { expenditures }\end{array}$ & $\begin{array}{l}\text { Differentiation } \\
\text { of services }\end{array}$ & $\begin{array}{l}\text { Focusing on } \\
\text { individual } \\
\text { segments }\end{array}$ \\
\hline 1 & 2 & 3 & 4 & 5 \\
\hline $\begin{array}{l}\text { 1. Factors of macro-, micro- } \\
\text { environment (according to } \\
\text { the rank of influence) }\end{array}$ & $\begin{array}{l}\text { Seeking the ways to } \\
\text { obtain competitive } \\
\text { advantages: } \\
\text { a) responding to } \\
\text { changes that are } \\
\text { taking place in the } \\
\text { tourism industry; } \\
\text { b) development of } \\
\text { competitive } \\
\text { measures and } \\
\text { actions that give } \\
\text { sustainable } \\
\text { advantages over } \\
\text { competitors. }\end{array}$ & $\begin{array}{l}\text { 1. Influence of } \\
\text { competitors - } 5 \\
\text { points; } \\
\text { 2. Influence of the } \\
\text { input sector } \\
\text { barrier - } 5 \\
\text { points; } \\
\text { 3. Impact of socio- } \\
\text { economic trends } \\
-4 \text { points. }\end{array}$ & $\begin{array}{l}\text { 1. Influence of } \\
\text { tourism market } \\
\text { parameters - } 5 \\
\text { points; } \\
\text { 2. Influence of } \\
\text { consumer } \\
\text { behavior }-4,5 \\
\text { 3. Influence of } \\
\text { competitors }-4 \\
\text { points. }\end{array}$ & $\begin{array}{l}\text { 1. Impact of } \\
\text { tourism market } \\
\text { parameters - } 5 \\
\text { points; } \\
\text { 2. Influence of } \\
\text { consumer } \\
\text { behavior - } 5 \\
\text { points; } \\
\text { 3. Influence of } \\
\text { the input } \\
\text { branch barrier } \\
\text { - } 5 \text { points; } \\
\text { 4. Influence of } \\
\text { competitors - } 3 \\
\text { points. }\end{array}$ \\
\hline 2. Aims. & $\begin{array}{l}\text { Concentration of } \\
\text { investments in } \\
\text { segments where } \\
\text { profitability is high and } \\
\text { the level of risk is low. }\end{array}$ & $\begin{array}{l}\text { Ensure the level of } \\
\text { expenditures that } \\
\text { allows the scale } \\
\text { effect. }\end{array}$ & $\begin{array}{l}\text { Creating and } \\
\text { expanding the } \\
\text { boundaries of } \\
\text { service and the } \\
\text { impact on the } \\
\text { competitiveness } \\
\text { of the service. }\end{array}$ & $\begin{array}{l}\text { Creating a } \\
\text { motivated target } \\
\text { consumer on the } \\
\text { basis of the } \\
\text { long-term } \\
\text { relationship } \\
\text { concept. }\end{array}$ \\
\hline
\end{tabular}

Source: own development of the authors.

The purpose of these strategies is to create and expand the range of service and influence on the competitiveness of the service, as well as to promote the long-term relations between the consumer and the tourist enterprise.

Therefore, it can be assumed that the model of the strategic marketing management system allows to carry out an alternative choice of interrelated business and marketing strategy.

\section{Conclusions}

As a result of the researches, an important scientific task of the theoretical principles expansion was solved, as well as the issue of the development of methodological basis and practical recommendations regarding the formation of the system of strategic marketing management in tourist enterprises in conditions of uncertainty of the market environment.

Consequently, the problems associated with the alternative strategic marketing management of tourism enterprises in the market environment uncertainty, are aimed at introducing the system approach that allows to achieve the interrelated goals of the enterprise.
The advantages of introducing a systematic approach to strategic marketing management of enterprises include the increase of the enterprise's adaptability to the uncertainty of the macroeconomic, microeconomic and internal environment of tourism enterprises, simplifying the process of strategic management of enterprises, increasing the awareness of enterprises about the existing strengths and opportunities, weaknesses and threats of enterprises, providing the competitive advantages of enterprises.

Based on the results of the analysis of factors of macroeconomic impact, the dependence between the volume of tourist flows of the travelling population abroad and such factors as: the amount of the GRP, the average income level of the population, the level of the unemployed population, the level of social benefits, the level of migration movement is confirmed.

The use of strategic marketing tools such as: SWOT analysis, $\mathrm{ABC}$ and $\mathrm{XYZ}$ analysis, and the BCG matrix, can identify the strengths and weaknesses of the enterprise, with the goal of further developing capabilities and eliminating threats at tourism enterprises in the Kherson region. 
Establishing the relationship between the spheres of organizational management and marketing in the market of tourist services allows, by the method of research questionnaire, to determine the list of prevailing socio-demographic characteristics of target consumers of tourism services, the list of microeconomic and internal factors that affect the image of the tourist enterprise and the qualitative perception of the tourist service. Multi-level economic and mathematical processing of the research questionnaire allows to rank and select the most successful indicators for mapping two-level and multi-level segmentation.

The proposed matrix of convergence of marketing tools to strategic management decisions helps to deepen the cooperation of management entities, their association, interaction and interconnections between components of the management system. In this case, the integration between individual subsystems and components of the management system is provided by enhancing and specifying the interconnections between them. The very process of marketing integration in the management is the consistency of goals, strategies and tactics between the two areas of the enterprise.

Competitive strategies focus on the actions and approaches that are related to the strategic marketing management and are aimed at ensuring successful tourism activities, which has oligopolistic players on the market. Within the framework of the strategic marketing management system, it is proposed to develop and select marketing strategies in five stages, which include: estimating the attractiveness of the macro- and microenvironment with the scale of the assessment of the environmental stage.

\section{References}

[1]. Burdenyuk, T. H. (2014). Stratehichnyy analiz kryteriyiv konkurentospromozhnosti pidpryyemstv / T.H. Burdenyuk // Problemy teoriyi ta metodolohiyi bukhhalters'koho obliku, kontrolyu i analizu.№ 1 (28). - S. 39-50. [in Ukrainian].

[2]. Lukashevich O.F. (2009). Znachennya stratehichnoho analizu $\mathrm{V}$ systemi stratehichnoho upravlinnya hospodars'kymy orhanizatsiyamy / O.F. Lukashevych // Ekonomika i prohnozuvannya. - 2009. - № 2. - S. 138-143. [in Ukrainian].

[3]. Cаух, I. В. (2014). Передумови виникнення та особливості стратегічного менеджменту вітчизняних підприємств.. Journal of ZHSTU. Series: Economics. 3 (69), pp.179-186. [in Ukrainian].

[4]. Shandova, N. (2017). Investigation of organizational and management specifics of health tourism development. Technology audit and production reserves, $(3$ (5)), 4-8.

[5]. Shandova N. V. \& Bilim E.S. (2018) Factors influencing the development of tourist attractiveness of the region. Economy. Finances. Right. No7, pp. 2124. [in Ukrainian].

[6]. Shershniova Z.E. (2001). Strategic management: a teaching manual, Kyiv: KNEU, p. 384 p.

[in Ukrainian].

[7]. Taraban S. (2009). Formation of Information and Organizational Provisions for the Making of Management Decisions. State and Regions. Series: Public Administration, 1, pp.157-161.

[8]. Voskresens'ka, O. YE. (2013). Systemnyy pidkhid do stratehichnoho marketynhovoho upravlinnya pidpryyemstvom. Modelyuvannya rehional'noyi ekonomiky, 104. [in Ukrainian].

[9]. Voskresens'ka, O. YE., \& Savchuk, O. A. (2011). Rozshyrennya instrumentariyu stratehichnoho planuvannya. Ekonomichni innovatsiyi, 45, pp.55-60. [in Ukrainian].

[10]. Vahner, I. M. (2009). Stratehichnyy analiz v umovakh nevyznachenosti. IM Vahner/Visnyk universytetu bankivs'koyi spravy Natsional'noho banku Ukrayiny, (2), 5. [in Ukrainian].

[11]. Official site of the State Statistics Service of Ukraine. (n.d.), ukrstat.gov.ua. Retrieved from: http: www.ukrstat.gov.ua. [accessed: 10 January 2020]. 